\title{
PENGARUH KOMPENSASI DAN MOTIVASI TERHADAP KINERJA KARYAWAN DI BIMBINGAN BELAJAR MATRIK PALEMBANG Amrillah Azrin ${ }^{1}$, Salman ${ }^{2}$
}

2,2 Dosen jurusan Manajemen, Universitas Tridinanti, Sumatera Selatan

1)Email : amrillahazrin62@gmail.com

\begin{tabular}{|c|c|}
\hline INFORMASI ARTIKEL & $\begin{array}{l}\text { ABSTRAK } \\
\text { Pengaruh Kompensasi dan Motivasi Terhadap Kinerja Karyawan pada }\end{array}$ \\
\hline $\begin{array}{l}\text { Submitted: } \\
06 / 01 / 2021\end{array}$ & $\begin{array}{l}\text { Bimbingan Belajar Matriks Palembang. Dengan menggunakan Analisis } \\
\text { Regresi Linier Berganda, Analisis Koefisien Korelasi, Analisis Determinasi }\end{array}$ \\
\hline $\begin{array}{l}\text { Revised: } \\
25 / 05 / 2021\end{array}$ & $\begin{array}{l}\text { dan Uji Hipotesis. Adapun untuk penelitian ini sampel yang dipilih adalah } \\
\text { seluruh } 40 \text { karyawan Bimbingan Belajar Matriks Palembang. Hasil penelitian }\end{array}$ \\
\hline $\begin{array}{l}\text { Accepted: } \\
27 / 06 / 2021\end{array}$ & $\begin{array}{l}\text { ini diperoleh pengaruh Kompensasi dan Motivasi secara simultan ( } f \text { ). Hasil } \\
\text { analisis regresi linier berganda yang dilakukan dalam penelitian ini diperoleh }\end{array}$ \\
\hline $\begin{array}{l}\text { Online-Published: } \\
30 / 06 / 2021\end{array}$ & $\begin{array}{l}\text { persamaan regresi sebagai berikut: } Y=-0,081+1,825 X 1+0,538 X 2+e . \\
\text { Variabel kompensasi dan motivasi mempunyai koefisien arah yang positif } \\
\text { terhadap kinerja karyawan, artinya semakin tinggi kompensasi dan motivasi } \\
\text { maka semakin tinggi kinerja karyawan maka angka } R \text { Square adalah } 0,863 \\
\text { atau }(85,6 \%) \text {. Hal ini menunjukkan bahwa persentase kontribusi pengaruh } \\
\text { variabel independen (Kompensasi dan Motivasi) terhadap variabel dependen } \\
\text { (Kinerja Karyawan) adalah } 85,6 \% \text {. Atau variasi variabel bebas yang } \\
\text { digunakan dalam Kompensasi dan Motivasi mampu menjelaskan } 85,6 \% \text { dari } \\
\text { variasi variabel terikat (Kinerja Karyawan). Sedangkan sisanya sebesar } \\
14,4 \% \text { dipengaruhi oleh variabel lain. }\end{array}$ \\
\hline
\end{tabular}

Kata kunci: Kompensasi, motivasi, kinerja

\begin{abstract}
ABSTRACK
The Effect of Compensation and Motivation on Employee Performance in the Palembang Matrix Tutoring. By using Multiple Linear Regression Analysis, Correlation Coefficient Analysis, Determination Analysis and Hypothesis Testing. As for this study, the sample selected was all 40 employees at the Palembang Matrix Learning Guidance. The results of this study obtained the effect of Compensation and Motivation simultaneously (f). The results of multiple linear regression analysis carried out in this study obtained the following regression equation: $Y=-0.081+1.825 X 1+0.538 X 2+e$. The compensation and motivation variables have a positive direction coefficient on employee performance, meaning that the higher the compensation and motivation, the higher the employee's performance, the $R$ Square number is 0.863 or $(85.6 \%)$. This shows that the percentage contribution of the influence of the independent variable (Compensation and Motivation) to the dependent variable (Employee Performance) is $85.6 \%$. Or the variation of the independent variables used in Compensation and Motivation is able to explain $85.6 \%$ of the variation in the dependent variable (Employee Performance). While the remaining $14.4 \%$ is influenced by other variables.
\end{abstract}

Keywords: Compensation, motivation, performance

\section{A. PENDAHULUAN}

Manusia merupakan faktor penting bagi suatu perusahaan guna menjaga kelangsungan hidup perusahaan dan untuk dapat menghadapi persaingan dalam dunia bisnis yang semakin ketat. Karyawan sebagai sumber daya perusahaan merupakan perencana, pelaksana, dan pengendali yang selalu berperan aktif dalam mewujudkan tujuan perusahaan. Karyawan menjadi pelaku yang menunjang tercapainya tujuan, mempunyai tujuan, mempunyai fikiran, perasaan dan keinginan yang dapat mempengaruhi sikap-sikapnya terhadap pekerjaannya. Sehingga dari sikap karyawan inilah muncul Motivasi, Komitmen Karyawan, dan Prestasi kerja karyawan 
terhadap pekerjaan yang dibebankan kepadanya.

Manjemen sumber daya manusia merupakan salah satu paling penting dalam suatu perusahaan. Berbanding lurus dengan hal tersebut, manusia juga merupakan sumber daya yang paling rumit untuk dipahami.Kerumitan ini adalah sebagai akibat dari uniknya sifat dari masing-masing individu yang ada di dunia,khusus dunia kerja. Masing-masing individu membutuhkan penanganan yang khusus untuk menjamin konstribusi karyawan pada perusahaan berjalan dengan maksimal.

Sumber Daya Manusia sebagai penggerak organisasi dalam mencapai tujuan perusahaan, maka perusahaan berkompetisi untuk memperoleh sumber daya yang berkualitas, karena kualitas hasil pekerjaan di tentukan oleh kompetensi yang dimiliki sumber daya manusianya. Alasan ini membuat banyak organisasi melakukan beberapa cara untuk mewujudkan kinerja yang baik dan dapat dicapai dengan melalui pendidikan dan pelatihan, pemberian kompensasi yang layak, menciptakan lingkungan kerja yang kondusif dan pemberian motivasi. Melalui cara tersebut diharapkan lebih memaksimalkan tanggung jawab atas pekerjaan mereka karena para karyawan telah terbekali ilmu yang mereka dapat.

Setiap individu mempunyai kepentingan dan tujuan tersendiri ketika ia bergabung pada organisasi tersebut. Bagi sebagian karyawan, harapan untuk mendapatkan uang adalah salah satu alasan untuk bekerja dan sebagiannya lagi untuk mendapatkan jabatan yang tinggi. Sehingga dari pihak perusahaanpun perlu memperhatikan pemberiaan kompensasi dan pengembangan karir sebagai imbalan yang layak untuk sebuah penghargaan terhadap apa yang telah dikerjakan karyawan. Akan tetapi pengembangan karir yang di dapat karyawan berkesempatan juga mendapatkan uang yang lebih banyak.

Kompensasi adalah semua pendapatan yang berbentuk uang,barang langsung atau tidak langsung yang diterima mitra sebagai imbalan atas jasa yang diberikan kepada karyawan. .Program kompensasi mencerminkan upaya organisasi untuk mempertahankan sumber daya manusia yang dimiliki. Pemberian kompensasi yang makin baik akan mendorong mitra untuk bekerja dengan makin baik dan produktif (Hasibuan, 2012 : 118 )

Kompensasi sangat berpengaruh terhadap kinerja karyawan di sebuah perusahaan, jika kompensasi diberikan secara tepat maka kinerja karyawan bisa meningkat dan begitupun sebaliknya. Menurut Sedarmayanti (2011:239) menyatakan bahwa kompensasi adalah : Segala sesuatu yang diterima oleh karyawan sebagai balas jasa kerja mereka.

Tujuan pemberian kompensasi menurut Hasibuan (2012:121) Mengemukakan beberapa tujuan kompensasi, antara lain : ikatan kerja sama, kepuasan kerja, pengadaan efektif, motivasi, stabilitas karyawan, disiplin, pengarus serikat buruh, pengaruh pemerintah.oleh karena itu, untuk menarik calon karyawan masuk dalam organisasi, organisasi harus merangsang calon pelamar dengan tingkat kompensasi yang cukup kompetitif dengan tingkat kompensasi dengan kompensasi organisasi lain.

Besarnya balas jasa ditentukan dan diketahui sebelumnya, sehingga karyawan secara pasti mengetahui besarnya balas jasa/kompensasi yang akan diterimanya. Besarnya kompensasi yang diterima karyawan menentukan kinerja karyawan itu sendiri, dengan demikian kepuasan kerja karyawan juga semakin baik.

Setiap perusahaan tentu menginginkan karyawannya mempunyai prestasi yang baik, karena tercapai atau tidaknya tujuan perusahaan dipengaruhi oleh kinerja karyawan di perusahaan. Menurut Simamora (2004:4), sumber daya manusia yang efektif sebagai salah satu sumber daya organisasi/perusahaan yang penting bagi keberhasilan perusahaan dalam mencapai tujuannya. Mengingat begitu pentingnya peranan sumber daya manusia dalam suatu perusahaan, sudah sepatutnya jika suatu perusahaan memperhatikan aspek-aspek kerja 
yang berkaitan dengan sumber daya manusia. Karena karyawan yang memiliki motivasi kerja yang kuat merupakan keunggulan kompetitif suatu perusahaan. Persoalan dalam memotivasi karyawan tidak mudah karena dalam diri karyawan terdapat keinginan, kebutuhan dan harapan yang berbeda antara satu karyawan dengan karyawan lain.

Motivasi adalah hal yang menyebabkan, menyalurkan, dan mendukung perilaku manusia, supaya mau bekerja giat dan antusias mencapai hasil yang optimal. Menurut Hasibuan (2007:141). Sedangkan menurut Abraham Maslow, "Motivasi adalah merupakan sejumlah proses-proses psikologikal yang menyebabkan timbulnya diarahkanya, dan terjadi persistensi kegiatankegiatan sukarela yang diarahkan ke tujuan tertentu, baik yang bersifat internal atau ekstensi bagi seorang individu yang menyebabkan timbulnya sikap antusiasme dan presistensi”. Jadi apabila manajemen dapat memahami persoalan motivasi dan mengatasinya maka perusahaan akan mendapatkan karyawan yang optimal sesuai dengan standar yang di tentukan.

Setiap perusahaan akan selalu berusaha untuk meningkatkan kinerja para karyawan, begitu juga dengan Bimbingan Belajar Matrik Palembang ini dan kinerja dapat tercapai apabila karyawan di dukung dengan adanya Motivasi. Jadi apabila manajemen dapat memahami persoalan motivasi dan mengatasinya maka perusahaan akan mendapatkan karyawan yang optimal sesuai dengan standar yang di tentukan. Penelitian yang akan dilakukan bertujuan bagaimana "Pengaruh Kompensasi Dan Motivasi Terhadap Kinerja Karyawan di Bimbingan Belajar Matrik Palembang"

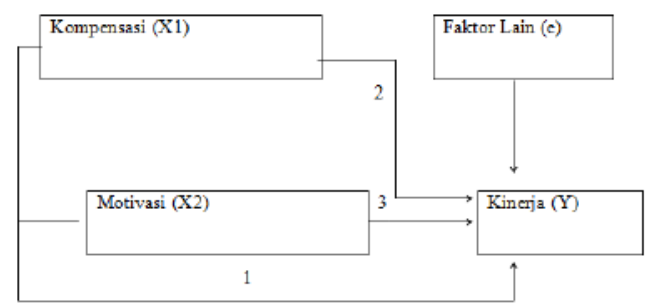

Gambar 1. Kerangka Berpikir Penelitian

\section{B. METODE PENELITIAN}

\section{Sumber Data dan Teknik Pengumpulan Data}

Berdasarkan cara memperolehnya menurut "Arikunto (2010) antara lain :

1. Data Primer

Yaitu data yang dikumpulkan langsung oleh peneliti melalui kuesioner, observasi, dan wawancara secara langsung dengan pimpinan dan staf perusahaan sesuai kebutuhan dalam penelitian.

2. Data Sekunder

Yaitu yang didapat tidak secara langsung dari objek peneliti. Peneliti mendapatkan data yang sudah jadi baik yang dikumpulkan oleh pihak lain dengan berbagai cara atau metode baik secara komersial maupun non komersial.

\section{Teknik Pengumpulan Data}

Metode pengumpulan data yang digunakan dalam penelitian ini adalah :

a. Kuesioner

Kuesioner adalah metode pengumpulan data yang dilakukan dengan cara memberikan pertanyaan - pertanyaan kepada responden dengan panduan kuesioner.

b. Observasi

Metode penelitian dimana peneliti melakukan pengamatan secara langsung pada objek penelitian.

c. Wawancara

Wawancara adalah metode pengumpulan data yang digunakan untuk memperoleh data - data dan informasi yang diperlukan dengan jalan mengadakan wawancara secara langsung, baik itu dengan pimpinan ataupun karyawan di Bimbingan Belajar Matrik Palembang.

d. Studi Pustaka

Studi Pustaka merupakan metode pengumpulan data yang dilakukan dengan membaca buku - buku literature, jurnal - jurnal, referensi 
yang berkaitan dengan penelitian yang sedang dilakukan.

Populasi dalam penelitian ini adalah karyawan pada di Bimbingan Matrik Palembang yang berjumlah 40 Orang Hal ini sering dilakukan bila jumlah populasi relatif kecil, atau penelitian ini membuat general dengan kesalahan yang sangat kecil. Istilah lain sample jenuh adalah sensus, dimana semua anggota populasi dijadikan sample. (Sugiyono, 2013:122)

\section{Rancangan Penelitian}

Pengaruh dalam penelitian ini bersifat kuantitas atau hubungan sebab akibat dimana variabel indenpendenya adalah Kompensasi dan Motivasi, dan variabel dependennya adalah kinerja.

\section{Variabel dan Definisi Operasional \\ Variabel \\ Variabel}

Variabel adalah sekumpulan satu set data yang nilainya bervariasi. Setiap variabel harus dapat dijelaskan secara konseptual oleh sejumlah teori ilmiah. Dalam penelitian ini diajukan dua variabel yaitu variabel independen atau variabel bebas, serta variabel dependen atau variabel terikat.

\section{Definisi Operasional}

Definisi operasional adalah unsur penelitian yang memberitahukan bagaimana mengukur suatu variabel dengan kata definisi operasional sebagai petunjuk pelaksanaan mengukur suatu variabel. Penelitian ini bertujuan untuk mendapatkan gambaran objektif dari pengaruh Kompensasi dan Motivasi terhadap Kinerja.

Instrumen Penelitian

Pada penelitian ini alat yang digunakan oleh penulis untuk pengumpulan data penelitian dari sumber data guna dijadikan sebuah sample yaitu melalui daftar pertanyaan (kuensioner) kepada responden melakukan pengumpulan data digunakan skala likert.

1. Sangat Tidak Setuju (STS) dengan skor 1

2. Tidak Setuju (TS) dengan skor 2

3. Kurang Setuju (KS) dengan skor 3

4. Setuju (S) dengan skor 4

5. Sangat Setuju (SS) dengan skor 5

\section{Teknik Analisis Data} a. Uji Validitas

Uji validasi digunakan untuk mengetahui valid atau tidaknya suatu kuesioner. Kuesioner dikatakan valid apabila pernyataan pada kuesioner mampu mengungkapkan sesuatu yang akan diungkap oleh kuesioner tersebut.

\section{b. Uji Reabilitas}

Pengukuran reabilitas dilakukan dengan cara one shot atau pengukuran sekali saja dengan alat bantu SPSS uji statistic Cronbach Alpha $\geq 0.60$.

\section{Analisis Statistik Inferensial Berganda}

Analisis ini digunakan untuk mengetahui seberapa besar pengaruh variabel bebas yaitu :Kompensasi (X1), dan Motivasi (X2) terhadap variabel terikat yaitu Kinerja Karyawan (Y). $Y=\mathrm{a}+\mathrm{b}_{\mathrm{I}} \mathrm{X}_{\mathrm{I}}+\mathrm{b}_{2} \mathrm{X}_{2}+e$

\section{Analisis Koefisien Korelasi}

Untuk mengetahui hubungan antar variabel independen Kompensasi X1, Motivasi X2 dengan devenden Kinerja Y.

\section{c. Analisis}

Untuk mengetahui pengaruh antara variabel independent Kompensasi $\mathrm{X}_{1}$ Motivasi $\mathrm{X}_{2}$, terhadap kinerja karyawan digunakan analisis koefisien determinasi (penentu), yaitu koefisien naik turunnya variabel lainnya.

\section{d. Uji Hipotesis}

1. Secara Simultan digunakan (Uji Statistik F)

Dalam penelitian ini , Hipotesis yang digunakan adalah :

Ho : $b_{1}, b_{2}=0$ artinya tidak ada hubungan antara Kompensasi dan Motivasi bersama sama terhadap kinerja.

$\mathrm{H}_{1}: \mathrm{b}_{1}, \mathrm{~b}_{2} \neq 0$ artinya terdapat hubungan antara Kompensasi dan Motivasi bersama sama terhadap kinerja.

Dasar pengambilan keputusan adalah (Ghozali , 2011 ) adalah dengan menggunakan angka probabilitas signifikansi, yaitu :

a. Apabila probabilitas signifikansi > 0.05, maka Ho diterima dan Ha ditolak. 
b. Apabila probabilitas signifikansi $\leq$ 0.05, maka Ho ditolak dan Ha diterima.

2. Secara simultan digunakan Uji t

Uji $t$ digunakan untuk menguji signifikasi hubungan antara variabel $\mathrm{X}$ dan Y, apakah variabel X1 dan X2 (Kompensasi dan Motivasi ) benar- benar berpengaruh terhadap variabel Y ( Kinerja ) secara terpisah atau parsial (Ghozali, 2011 ). Hipotesis yang digunakan untuk dalam pengujian ini adalah :
Ho : $\mathrm{b}_{1}, \mathrm{~b}_{2}=0$ artinya Kompensasi dan Motivasi tidak mempunyai pengaruh yang signifikan terhadap kinerja.

$\mathrm{H}_{1}: \mathrm{b}_{1}, \mathrm{~b}_{2} \neq 0$ artinya Kompensasi dan Motivasi tidak mempunyai pengaruh yang signifikan terhadap kinerja.

C. HASIL DAN PEMBAHASAN

Uji Instrumen

Uji Validitas Variabel Kompensasi (X1)

\section{Tabel 1. Hasil Uji Validitas Variabel Kompensasi}

\begin{tabular}{|c|c|c|c|}
\hline No item & r Hitung & Syarat & Keterangan \\
\hline $\mathbf{1}$ & $\mathbf{0 , 6 3 6} * *$ & $\mathbf{0 , 3 1 2}$ & Valid \\
\hline $\mathbf{2}$ & $\mathbf{0 , 7 3 5} * *$ & $\mathbf{0 , 3 1 2}$ & Valid \\
\hline $\mathbf{3}$ & $\mathbf{0 , 6 6 6} * *$ & $\mathbf{0 , 3 1 2}$ & Valid \\
\hline $\mathbf{4}$ & $\mathbf{0 , 8 5 5} *$ & $\mathbf{0 , 3 1 2}$ & Valid \\
\hline $\mathbf{5}$ & $\mathbf{0 , 8 8 9} * *$ & $\mathbf{0 , 3 1 2}$ & Valid \\
\hline $\mathbf{6}$ & $\mathbf{0 , 8 4 9} *$ & $\mathbf{0 , 3 1 2}$ & Valid \\
\hline $\mathbf{7}$ & $\mathbf{0 , 8 2 8} * *$ & $\mathbf{0 , 3 1 2}$ & Valid \\
\hline $\mathbf{8}$ & $\mathbf{0 , 8 4 0} * *$ & $\mathbf{0 , 3 1 2}$ & Valid \\
\hline $\mathbf{9}$ & $\mathbf{0 , 8 0 9} * *$ & $\mathbf{0 , 3 1 2}$ & Valid \\
\hline 10 & $\mathbf{0 , 7 3 2} * *$ & $\mathbf{0 , 3 1 2}$ & Valid \\
\hline
\end{tabular}

Berdasarkan tabel diatas diperoleh nilai $r$ hitung untuk setiap butir pernyataan pada variabel Kompensasi $(\mathrm{X}$ ) $>\mathrm{r}$ tabel 0,632 dengan demikian maka dapat dijelaskan bahwa semua butir pernyataan variabel Kompensasi dinyatakan valid.

\begin{tabular}{|c|c|c|c|}
\hline No item & r Hitung & Syarat & Keterangan \\
\hline $\mathbf{1}$ & $\mathbf{0 , 8 1 0} * *$ & $\mathbf{0 , 3 1 2}$ & Valid \\
\hline $\mathbf{2}$ & $\mathbf{0 , 9 1 0} * *$ & $\mathbf{0 , 3 1 2}$ & Valid \\
\hline $\mathbf{3}$ & $\mathbf{0 , 8 2 7} * *$ & $\mathbf{0 , 3 1 2}$ & Valid \\
\hline $\mathbf{4}$ & $\mathbf{0 , 8 9 3} * *$ & $\mathbf{0 , 3 1 2}$ & Valid \\
\hline $\mathbf{5}$ & $\mathbf{0 , 9 1 7 * *}$ & $\mathbf{0 , 3 1 2}$ & Valid \\
\hline $\mathbf{6}$ & $\mathbf{0 , 9 3 7} * *$ & $\mathbf{0 , 3 1 2}$ & Valid \\
\hline $\mathbf{7}$ & $\mathbf{0 , 9 0 1 * *}$ & $\mathbf{0 , 3 1 2}$ & Valid \\
\hline $\mathbf{8}$ & $\mathbf{0 , 8 2 4} * *$ & $\mathbf{0 , 3 1 2}$ & Valid \\
\hline $\mathbf{9}$ & $\mathbf{0 , 8 3 2} *$ & $\mathbf{0 , 3 1 2}$ & Valid \\
\hline $\mathbf{1 0}$ & $\mathbf{0 , 7 2 4} *$ & $\mathbf{0 , 3 1 2}$ & Valid \\
\hline
\end{tabular}

Berdasarkan tabel diatas diperoleh nilai $r$ hitung untuk setiap butir pernyataan pada variabel motivasi( X2 ) > r tabel 0,312 dengan demikian maka dapat dijelaskan bahwa semua butir pernyataan variabel Motivasi dinyatakan valid.
Uji Validitas Variabel Motivasi( X2 )

Tabel 2. Hasil Uji Validitas Variabel Motivasi 


\begin{tabular}{|c|c|c|c|}
\hline No item & r Hitung & Syarat & Keterangan \\
\hline $\mathbf{1}$ & $\mathbf{0 , 8 5 9} * *$ & $\mathbf{0 , 3 1 2}$ & Valid \\
\hline $\mathbf{2}$ & $\mathbf{0 , 8 6 8} * *$ & $\mathbf{0 , 3 1 2}$ & Valid \\
\hline $\mathbf{3}$ & $\mathbf{0 , 8 2 6} * *$ & $\mathbf{0 , 3 1 2}$ & Valid \\
\hline $\mathbf{4}$ & $\mathbf{0 , 8 6 8} * *$ & $\mathbf{0 , 3 1 2}$ & Valid \\
\hline $\mathbf{5}$ & $\mathbf{0 , 8 9 0} * *$ & $\mathbf{0 , 3 1 2}$ & Valid \\
\hline $\mathbf{6}$ & $\mathbf{0 , 8 7 9} * *$ & $\mathbf{0 , 3 1 2}$ & Valid \\
\hline $\mathbf{7}$ & $\mathbf{0 , 9 2 9} * *$ & $\mathbf{0 , 3 1 2}$ & Valid \\
\hline $\mathbf{8}$ & $\mathbf{0 , 8 6 6}^{* *}$ & $\mathbf{0 , 3 1 2}$ & Valid \\
\hline $\mathbf{9}$ & $\mathbf{0 , 8 7 6} * *$ & $\mathbf{0 , 3 1 2}$ & Valid \\
\hline 10 & $\mathbf{0 , 9 2 5} * *$ & $\mathbf{0 , 3 1 2}$ & Valid \\
\hline
\end{tabular}

Berdasarkan tabel diatas diperoleh nilai $r$ hitung untuk setiap butir pernyataan pada variabel Kinerja Karyawan $(\mathrm{Y})>\mathrm{r}$ tabel 0,632 dengan demikian maka dapat dijelaskan bahwa semua butir pernyataan variabel Kinerja Karyawan dinyatakan valid.

\section{Uji Reliabilitas}

Tabel 4, Hasil Uji Reliabilitas

\begin{tabular}{|c|c|c|}
\hline Variabel & Cronbach Alpha & Keterangan \\
\hline Kompensasi & 0,966 & Reliabel \\
\hline Motivasi & 0,932 & Reliabel \\
\hline Kinerja karyawan & 0,960 & Reliabel \\
\hline
\end{tabular}

Berdasarkan tabel diatas diketahui bahwa semua variabel memiliki koefisien alpha > 0,632 dengan nilai cronbach Alpha yang dihasilkan melalui program SPSS 23 sehingga sesuai dengan landasan teori dapat dikatakan bahwa semua konsep pengukuran masing-masing variabel masing-masing kuisioner dapat diterima dan reliabel.

Teknik Analisis data

\section{Uji Analisis Regresi Berganda}

Analisis regresi linear berganda mengestimasikanbesarnya koefisienkoefisien yang dihasilkan oleh yang bersifat linear yang melibatkan dua variabel bebas untuk digunakan sebagai alat prediksi besarnya nilai variabel tergantung. Dari hasil perhitungan statistik yang menggunakan SPSS 23 yang tertera pada tabel berikut ini

Tabel 5. Regresi berganda

\begin{tabular}{|c|c|c|c|c|c|c|}
\hline \multicolumn{7}{|c|}{ Coefficients $^{a}$} \\
\hline \multirow{2}{*}{\multicolumn{2}{|c|}{ Model }} & \multicolumn{2}{|c|}{ Unstandardized Coefficients } & \multirow{2}{*}{$\begin{array}{c}\begin{array}{c}\text { Standardized } \\
\text { Coefficients }\end{array} \\
\text { Beta }\end{array}$} & \multirow[b]{2}{*}{$\mathrm{T}$} & \multirow[b]{2}{*}{ Sig. } \\
\hline & & B & Std. Error & & & \\
\hline 1 & (Constant) & -.081 & 2.856 & & -.028 & .978 \\
\hline & $x 1$ & 1.825 & .180 & 1.357 & 10.122 & .000 \\
\hline & $x 2$ & 538 & .140 & -.514 & 3.831 & .000 \\
\hline
\end{tabular}

a. Dependent Variable: y

Persamaan regresinya sebagai berikiut

$\mathrm{Y}=\mathrm{a}+\mathrm{b}_{1} \mathrm{X}_{1}+\mathrm{B}_{2} \mathrm{X}_{2}+\mathrm{e}$

$Y=-0,081+1,825 X_{1}+0,538 X_{2}+e$

Artinya : a. merupakan nilai konstanta, jika nilai variabel Kompensasi X1 dan variabel motivasi $\mathrm{X} 2$ adalah 0 , maka Kinerja Karyawan ( Y ) sebesar- 0,081

b. Menyatakan bahwa setiap peningkatan satu satuan skala pada variabel 
kompensasi (X1) maka akan memberikan kenaikan pada variabel Kinerja Karyawan( Y ) sebesar 1,825

c. Menyatakan bahwa setiap seningkatan satu satuan skala pada variabel
Motivasi( X2 ) maka akan memberikan kenaikan pada variabel Kinerja Karyawan( Y ) sebesar 0,538

\section{Tabel 6. Koefisien Korelasi}

\begin{tabular}{|rl|r|r|r|}
\hline \multicolumn{5}{|c|}{ Correlations } \\
\hline x1 & \multicolumn{1}{c|}{$\mathrm{x} 1$} & \multicolumn{1}{c|}{ x2 } & \multicolumn{1}{c|}{$\mathrm{Y}$} \\
& Pearson Correlation & 1 & $.891^{* *}$ & $.899^{* *}$ \\
& Sig. (2-tailed) & & .000 & .000 \\
& $\mathrm{~N}$ & 40 & 40 & 40 \\
\hline x2 & Pearson Correlation & $.891^{* *}$ & 1 & $.696^{* *}$ \\
& Sig. (2-tailed) & .000 & & .000 \\
& N & 40 & 40 & 40 \\
\hline Y & Pearson Correlation & $.899^{* *}$ & $.696^{* *}$ & 1 \\
& Sig. (2-tailed) & .000 & .000 & \\
& N & 40 & 40 & 40 \\
\hline
\end{tabular}

${ }^{* *}$. Correlation is significant at the 0.01 level (2-tailed).

Berdasarkan tabel diatas hasil uji analisa koefisien korelasi diketahui antara Kompensasi (X1) dan Kinerja Kayawan (Y) $0,00<0,05$ yang berarti terdapat korelasi yang signifikan. Selanjutnya antara Motivasi (X2) dan Kinerja Karyawan (Y) nilai signifikan $0,00<0,05$ yang berarti terdapat korelasi yang signifikan. Terakhir antara kompensasi ( X1 ) dan Motivasi ( X2 ) nilai signifikan $0,00<0,05$ yang berarti terdapat korelasi yang signifikan.

\section{Koefisien Determinasi (R2)}

Model Summary

\begin{tabular}{|l|r|r|r|r|}
\hline Model & $\mathrm{R}$ & $\mathrm{R}$ Square & \multicolumn{1}{c|}{$\begin{array}{l}\text { Adjusted R } \\
\text { Square }\end{array}$} & $\begin{array}{l}\text { Std. Error of the } \\
\text { Estimate }\end{array}$ \\
\hline 1 & $.929^{\mathrm{a}}$ & .863 & .856 & 2.866 \\
\hline
\end{tabular}

a. Predictors: (Constant), x2, x1

b. Dependent Variable: y

Berdasarkan tebel di atas diperoleh angka R Square sebesar 0,863 atau ( $85,6 \%$ ). Hal ini menunjukan bahwa presentase sumbangan pengaruh variabel independen (Kompensasi Dan Motivasi) terhadap variabel dependen (Kinerja Karyawan) sebesar $85,6 \%$. Atau variasi variabel
Pengujian ini dilakukan untuk mengukur tingkat kemampuan model dalam menjelaskan variabel independen. Nilai determinasi R2 mengandung kelemahan dimana adanya kemungkinan terjadinya bias terhadap jumlah variabel independen yang dimasukan dalam model. Oleh karena itu dalam penelitian ini menggunakan koefisien determinasi yang disesuaikan (adjusted $R 2$ ).

\section{Tabel 7. Koefisien Determinasi}




\section{Uji Hipotesis}

\section{Uji Signifikan Simultan ( uji F )}

Pada dasar nya uji f menunjukan seberapa jauh pengaruh satu variabel independent secara parsial dalam menerangkan variasi variabel dependent. Dari hasil perhitungan statistik yang menggunakan SPSS 23 yang tertera pada tabel sebagai berikut :

\section{Tabel 8. Uji F}

ANOVA $^{\mathrm{a}}$

\begin{tabular}{|ll|r|r|r|r|r|}
\hline \multicolumn{1}{|l|}{ Model } & Sum of Squares & \multicolumn{1}{|c|}{ Df } & Mean Square & F & Sig. \\
\hline 1 & Regression & 1914.876 & 2 & 957.438 & 116.569 & $.000^{\mathrm{b}}$ \\
& Residual & 303.899 & 37 & 8.213 & & \\
& Total & 2218.775 & 39 & & & \\
\hline
\end{tabular}

a. Dependent Variable: $y$

b. Predictors: (Constant), x2, x1

Tebel menunjukan hasil pengujian signifikan $F$ simultan. Dari hasil itu menunjukan bahwa variabel independen secara bersama memiliki pengaruh yang signifikan terhadap variabel dependen, ini di karnakan nilai signifikan $\mathrm{f} 0,00<0,05$. Hal ini membuktikan bahwa Kompensasi( X1) dan Motivasi ( X2) secara bersama -sama memiliki pengaruh pada Kinerja Karyawan.

\section{Uji t ( uji parsial )}

Pada dasar nya uji $t$ menunjukan seberapa jauh pengaruh satu variabel independent secara parsial dalam menerangkan variasi variabel dependent. Dari hasil perhitungan statistik yang menggunakan SPSS 23 yang tertera pada tabel sebagai berikut :

\section{Tabel 9. Uji t}

\begin{tabular}{|c|c|c|c|c|c|c|}
\hline \multicolumn{7}{|c|}{ Coefficients $^{a}$} \\
\hline \multirow{2}{*}{\multicolumn{2}{|c|}{ Model }} & \multicolumn{2}{|c|}{ Unstandardized Coefficients } & \multirow{2}{*}{$\begin{array}{l}\text { Standardized } \\
\text { Coefficients } \\
\text { Beta }\end{array}$} & \multirow[b]{2}{*}{$\mathrm{T}$} & \multirow[b]{2}{*}{ Sig. } \\
\hline & & B & Std. Error & & & \\
\hline 1 & (Constant) & -.081 & 2.856 & & -.028 & .978 \\
\hline & $\mathrm{x} 1$ & 1.825 & .180 & 1.357 & 10.122 & .000 \\
\hline & $x 2$ & .538 & .140 & -.514 & 3.831 & .000 \\
\hline
\end{tabular}

a. Dependent Variable: y

Hasil dari uji t ( parsial ) diatas, diketahui nilai $\mathrm{t}$ hitung adalah 10,122 , ini berarti nilai $\mathrm{t}$ hitung lebih besar dari nilai $\mathrm{t}$ tabel 2.021 ( berdasarkan t tabel ). Sedangkan untuk nilai signifikansi Kompensasi ( X1) $0,00<0,05$ yang berrti Ho ditolak dan $\mathrm{Ha}$ diterima. Berarti ada pengaruh signifikan antara variabel Kompensasi(X1) dan Kinerja Karyawan (Y).

Selanjutnya, uji t (parsial ) diketahui t hitung sebesar 3,831 lebih besar dari t tabel 2,021 ( berdasarkan $t$ tabel) dan signifikansi variabel Motivasi ( X2) $0,00<0,05$. Artinya Ho ditolak dan Ha diterima. Berarti ada pengaruh yang signifikan antara Motivasi (X2) dan Kinerja Karyawan ( Y ).

Menurut "Sastrohadiwiryo dalam Buku Yuniarsih (2011:125) menyimpulkan bahwa kompensasi adalah suatu balas jasa yang diterima oleh karyawan, yang diberikan oleh berdasarkan kinerja karyawan, dan bertujuan untuk meningkatkan kesejahteraan dan produktivitas karyawan.

Dan menurut Abraham Maslow, "Motivasi adalah merupakan sejumlah proses-proses psikologikal, yang menyebabkan timbulnya diarahkannya, dan terjadi persistensi kegiatan-kegiatan sukarela 
yang diarahkan ke tujuan tertentu, baikyang bersifat internal atau ekstensi bagi seorang individu yang menyebabkan timbulnya sikap antusiasme dan presistensi". Dari definisi diatas tersebut dapat dijelaskan bahwa dalam memotivasi bawahan, manajer hendaknya menyediakan fasilitas, menciptakan suasana pekerjaan yang baik, dan memberikan kesempatan untuk promosi. Dengan demikian, memungkinkan para bawahan meningkatkan semangat kerjanya untuk mencapai tujuan dari perusahaan.

\section{SIMPULAN DAN SARAN}

1. Simpulan

1. Hasil analisis regresi linier berganda pada penelitian ini didapat persamaan regresi sebagai berikut $=$

$0,081+1,825 \mathrm{X}_{1}+0,538 \mathrm{X}_{2}+\mathrm{e}$.

Variabel kompensasi dan

Motivasi mempunyai arah

koefisien yang bertanda positif terhadap kinerja karyawan, artinya makin tinggi Kompensasi dan Motivasi maka makin tinggi pula kinerja karyawan di Bimbingan Belajar Matrik Palembang. Hasil Uji Analisis Regresi Berganda, bahwa Variabel Kinerja negatif, artinya makin rendah kompensasi dan motivasi maka makin menurun pula kinerja karyawan, dan data tersebut diperoleh sebesar $8,1 \%$.

2. $\mathrm{R}$ Square sebesar 0,863 atau ( 85,6\%). menunjukan bahwa presentase sumbangan pengaruh variabel independen (Kompensasi Dan Motivasi ) terhadap variabel dependen (Kinerja Karyawan) sebesar 85,6\%. Atau variasi variabel independen yang digunakan dalam Kompensasi dan Motivasi mampu menjelaskan sebesar $85,6 \%$ variasi variabel dependen (Kinerja Karyawan). Sedangkan sisanya sebesar $14,4 \%$ di pengaruhi atau di jelaskan oleh variabel lain yang tidak di masukan dalam model penelitian ini.

3. Dari hasil analisa data yang dilakukan peneliti antara Motivasi (X2) dan Kinerja Karyawan ( Y ) nilai signifikan $0,00<0,05$ yang berarti terdapat korelasi yang signifikan. Hasil pengujian signifikan F simultan. Dari hasil itu menunjukan bahwa variabel independen secara bersama memiliki pengaruh yang signifikan terhadap variabel dependen, ini di karenakan nilai signifikan $f 0,00<0,05$. Hal ini membuktikan bahwa Kompensasi (X1) dan Motivasi ( X2) secara bersama -sama memiliki pengaruh pada Kinerja Karyawan.

4. Hasil dari uji t ( parsial ), nilai t hitung adalah 10,122, ini berarti nilai $t$ hitung lebih besar dari nilai t tabel 2.021 ). Sedangkan untuk nilai signifikansi Kompensasi (X1) 0,00<0,05 yang berarti Ho ditolak dan $\mathrm{Ha}$ diterima. Berarti ada pengaruh signifikan antara variabel Kompensasi(X1) dan Kinerja Karyawan (Y). Selanjutnya, uji $\mathrm{t}$ (parsial ) sebesar 3,831 lebih besar dari $\mathrm{t}$ tabel 2,021 dan signifikansi variabel Motivasi ( X2) 0,00< 0,05. Artinya Ho ditolak dan Ha diterima. Berarti ada pengaruh yang signifikan antara Motivasi (X2) dan Kinerja Karyawan ( Y ).

\section{Saran}

1. . Kepada karyawan, hendaknya merasa bangga ketika berada dalam lingkungan kerja sehingga dapat memunculkan motivasi yang akan berkontribusi terhadap kinerja karyawan, ketika kinerja karyawan meningkat lembagapun akan memberikan timbal balik terhadap karyawan berupa bonus yang akan diberikan sesuai kinerjanya. 
2. Perusahaan hendaknya memberikan bonus kepada karyawan yang berprestasi dan memiliki kinerja yang baik, agar dapat lebih meningkatkan kinerja dan menjadi dorongan untuk karyawan yang lain.

3. Untuk penelitian yang akan datang, disarankan untuk mencari ruang lingkup populasi yang berbeda dan lebih luas dari populasi yang digunakan dalam penelitian ini, begitu pula dengan sampel yang digunakan, dengan demikian, penelitian yang dapat memberikan gambaran yang lebih spesifik mengenai kompensasi dan motivasi terhadap kinerja karyawan.

\section{E. DAFTAR RUJUKAN}

Arikunto, 2010. "Prosedur Penelitian : Suatu Pendekatan Praktik”. Edisi revisi 6, Rineka Cipta : Jakarta.

Ermaya, Suradinata. 2009. “Manajemen Sumber Daya Manusia”. Yogyakarta : PT. Andi Offset.

Hasibuan, Malayu. 2014. "Manajemen

Sumber Daya Manusia”. Jakarta : PT. Bumi Aksara.

Mangkunegara, 2003. "Riset Sumber Daya Manusia dalam Organisasi”. Edisi Revisi, PT. Gramedia Pustaka Umum, Jakarta

Mangkunegara, Anwar Prabu. 2009. “ Manajemen Sumber Daya Manusia Perusahaan". Bandung: Penerbit Refika Aditama.

Sedarmayanti. 2009. “Manajemen Sumber Daya Manusia dan Produktifitas

Kerja”. Bandung : CV. Mandar Maju.

Sofyandi, Herman. 2009. "Manajemen

Sumber Daya Manusia”. Yogyakarta : Graha Ilmu.
Sugiyono, 2013. “Metode Penelitian Kuantitatif, Kualitatif”. Alfabeta : Bandung.

Veitzal, Rivai dan Sagala Jauvani, 2009. "Manajemen Sumber Daya Manusia untuk Perusahaan”. Rajawali Pers, Jakarta. 